\title{
Lagomorph predation represented in a middle Palaeolithic level of the Navalmaíllo Rock Shelter site (Pinilla del Valle, Spain), as inferred via a new use of classical taphonomic criteria
}

\author{
M.C. Arriaza ${ }^{\text {a, b, * }, ~ R . ~ H u g u e t ~}{ }^{\mathrm{c}, \mathrm{d}, \mathrm{e}}$, C. Laplana ${ }^{\mathrm{f}}, \mathrm{A}$. Pérez-González ${ }^{\mathrm{g}}$, B. Márquez $^{\mathrm{f}}$, \\ J.L. Arsuaga ${ }^{\text {h, i }}$, E. Baquedano ${ }^{\text {b, f }}$ \\ a Departamento de Geología, Geografía y Medio Ambiente, Universidad de Alcalá, Edificio de Ciencias, Campus Externo, Ctra. A-II-km 33.600, \\ 28871 Alcalá de Henares, Madrid, Spain \\ b Instituto de Evolución en África (IDEA), Museo de los Orígenes, Plaza de San Andrés 2, 28005 Madrid, Spain

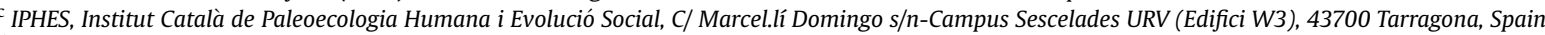 \\ ' Universitat Rovira $i$ Virgili, Avda. Catalunya 35, 43002 Tarragona, Spain \\ e Unidad asociada al CSIC, Departamento de Paleobiología, Museo Nacional de Ciencias Naturales, Calle José Gutierrez Abascal, 2, 28006 Madrid, Spain \\ ${ }^{\mathrm{f}}$ Museo Arqueológico Regional, Plaza de las Bernardas s/n, 28801 Alcalá de Henares, Madrid, Spain \\ ${ }^{g}$ Centro Nacional de Investigación sobre la Evolución Humana (CENIEH), Po Sierra de Atapuerca s/n, 09001 Burgos, Spain \\ ${ }^{\text {h }}$ Departamento de Paleontología, Universidad Complutense de Madrid, Avenida Complutense s/n, 28040 Madrid, Spain

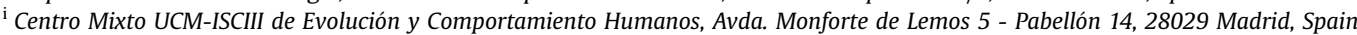

\section{A R T I C L E I N F O}

Article history:

Available online $\mathrm{xxx}$

\section{Keywords:}

Middle Palaeolithic

Taphonomy

Lagomorphs

Non-human predators

Deciduous teeth

Coprolites

\begin{abstract}
A B S T R A C T
Lagomorph remains at Pleistocene sites may accumulate through the action of hominins, raptors or carnivores. Actualistic studies have described reliable taphonomic indicators that allow human and nonhuman involvement in such accumulations to be distinguished. However, discriminating between possible animal predators is not easy, because the prey remnants they leave may undergo the same kinds of taphonomic transformation. The main aim of the present work was to identify the agent, human or non-human, that accumulated the lagomorph remains at the Navalmaíllo Rock Shelter site (Pinilla del Valle, Madrid). For this, 1) established taphonomic criteria, such as anatomical representation, were taken into account, 2) the presence of infant lagomorphs was examined by determining the age of the individual animals, 3) and coprolite remains adhered to fossils were identified. This new use of the latter two criteria aided in the identification of the predator responsible for the accumulation of remains. The results suggest that this was a small carnivore, probably an Iberian lynx.
\end{abstract}

๑) 2015 Elsevier Ltd and INQUA. All rights reserved.

\section{Introduction}

Many predators consume rabbits with great regularity; indeed, the rabbit is a key species of Mediterranean ecosystems. According to Delibes and Hiraldo (1981), and Delibes-Mateos and GálvezBravo (2009), some of its predators are opportunists, such as the ocellated lizard (Lacerta lepida) and the wild boar (Sus scrofa). However, rabbits are normally taken by carnivores and raptors. Some, such as the Spanish Imperial Eagle (Aquila adalberti) and the Iberian Lynx (Lynx pardinus), have become super-specialists.

* Corresponding author. Departamento de Geología, Geografía y Medio Ambiente, Universidad de Alcalá, Edificio de Ciencias, Campus Externo, Ctra. A-II-km 33.600, 28871 Alcalá de Henares, Madrid, Spain.

E-mail address: mcarmen.arriaza@uah.es (M.C. Arriaza).
The hominins of Europe consumed lagomorphs throughout the Pleistocene, but few sites dating from before the Upper Palaeolithic reflect such behaviour (Pillard, 1969; Chase, 1986; Blasco Sancho, 1995; Martínez Valle, 1996; Guennouni, 2001; Cochard, 2004; Costamagno and Laroulandie, 2004; Sanchís-Serra and Fernández-Peris, 2008; Cochard et al., 2012; Huguet et al., 2013). Many authors therefore consider the systematic consumption of such small prey to be largely associated with anatomically modern humans (Stiner, 1994; Villaverde et al., 1996; Stiner et al., 1999, 2000; Martínez del Valle, 2001; Aura-Tortosa et al., 2002; Hockett and Haws, 2002; Cochard and Brugal, 2004; Lloveras et al., 2011; Fa et al., 2013; Rodríguez-Hidalgo et al., 2013a). Carnivores and raptors were great hunters of rabbits throughout the Pleistocene, and many sites are home to accumulations of rabbit skeletal remains, some of which show traces of consumption (Pillard, 1972; Desclaux, 1992; 
Stiner, 1994; Blasco-Sancho, 1995; Martínez Valle, 1996; FernándezJalvo and Andrews, 2000; Guennouni, 2001; Cochard, 2004, 2007; Sanchís Serra and Fernández-Peris, 2008; Lloveras et al., 2010, 2011). In recent years, much effort has been invested in characterising the accumulations left by these predators, and in finding diagnostic features that might reveal the species responsible (Andrews, 1990; Schmitt and Juell, 1994; Hockett, 1996; Cruz-Uribe and Klein, 1998; Sanchís-Serra, 2000; Cochard, 2004; Yravedra, 2004; Lloveras et al., 2008a, 2008b, 2009a; Sanchís-Serra and Pascual-Benito, 2011; Lloveras et al., 2012a; Álvarez et al., 2012; Rodríguez-Hidalgo et al., 2013b). The majority of these diagnostic features have been obtained via actualistic studies. These are vital in understanding the processes that helped form archaeopalaeontological sites, in comprehending the strategies used in resource procurement by different predators (including hominins, carnivores and raptors), and in unveiling the relationships between species in palaeoecosystems. However, the limitations of this kind of study must be borne in mind: the taphonomic features left by different remain-accumulating agents may be very similar and even overlap. It can be hard to determine whether remains were left by carnivores or raptors since the associated body part frequencies and fragmentation, etc., can be very similar (Lloveras et al., 2011). Diagenetic agents can also distort the original characteristics of skeletal remains (Fernández-Jalvo, 1992), making the predator that discarded them even harder to identify. Thus, actualistic studies are important in coming to a taphonomic understanding, but the different post-depositional histories of modern and fossil remains should be taken into account when interpreting a site.

The main aim of the present work was to determine the predator responsible for the accumulation of lagomorph remains in Level F (middle Palaeolithic) at the Navalmaíllo Rock Shelter (Pinilla del Valle, Madrid, Spain). In its identification, use was made of the taphonomic criteria of Lloveras et al. (2008a, 2008b, 2009a, 2012a), which were obtained from different actualistic studies. In addition, a new use was made of classic taphonomic criteria to determine whether the examined accumulation was left by carnivores or raptors, i.e., establishing the age of the lagomorphs represented in the accumulation, and examining the coprolites present.

\section{Navalmaíllo Rock Shelter site}

The Calvero de la Higuera site complex in Pinilla del Valle (Madrid, Spain) lies in the upper valley of the River Lozoya located in the Sierra de Guadarrama; it is a NE-SW-aligned mountain range with a general pop-up structure that forms part of the Central System. The archaeological sites are associated with cavities in a gentle slope of Upper Cretaceous karst rock inclined towards the River Lozoya (which runs W-E $200 \mathrm{~m}$ to the north) (PérezGonzález et al., 2010) (Fig. 1). In 2002, excavations began at four sites: the Camino Cave, Navalmaíllo Rock Shelter, Buena Pinta Cave and Des-Cubierta Cave (Arsuaga et al., 2010, 2011, 2012; Baquedano et al., 2010, 2011/2012; Huguet et al., 2010; Pérez-González et al., 2010).

The Navalmaíllo Rock Shelter (Fig. 2) occupies an area of some $300-400 \mathrm{~m}^{2}$, of which some $80 \mathrm{~m}^{2}$ have been excavated. The stratigraphy of the examined sections can be described in synthesis, from the top downwards, as follows:

- Horizon wall A (Level A), $40 \mathrm{~cm}$ thick, greyish (10YR 5/2), siltysandy with dispersed clasts more abundant towards the base. Two coluvionary stages (Levels B and $\mathrm{B}^{\prime}$ ) have been identified, both composed of altered, floating carbonate clasts measuring

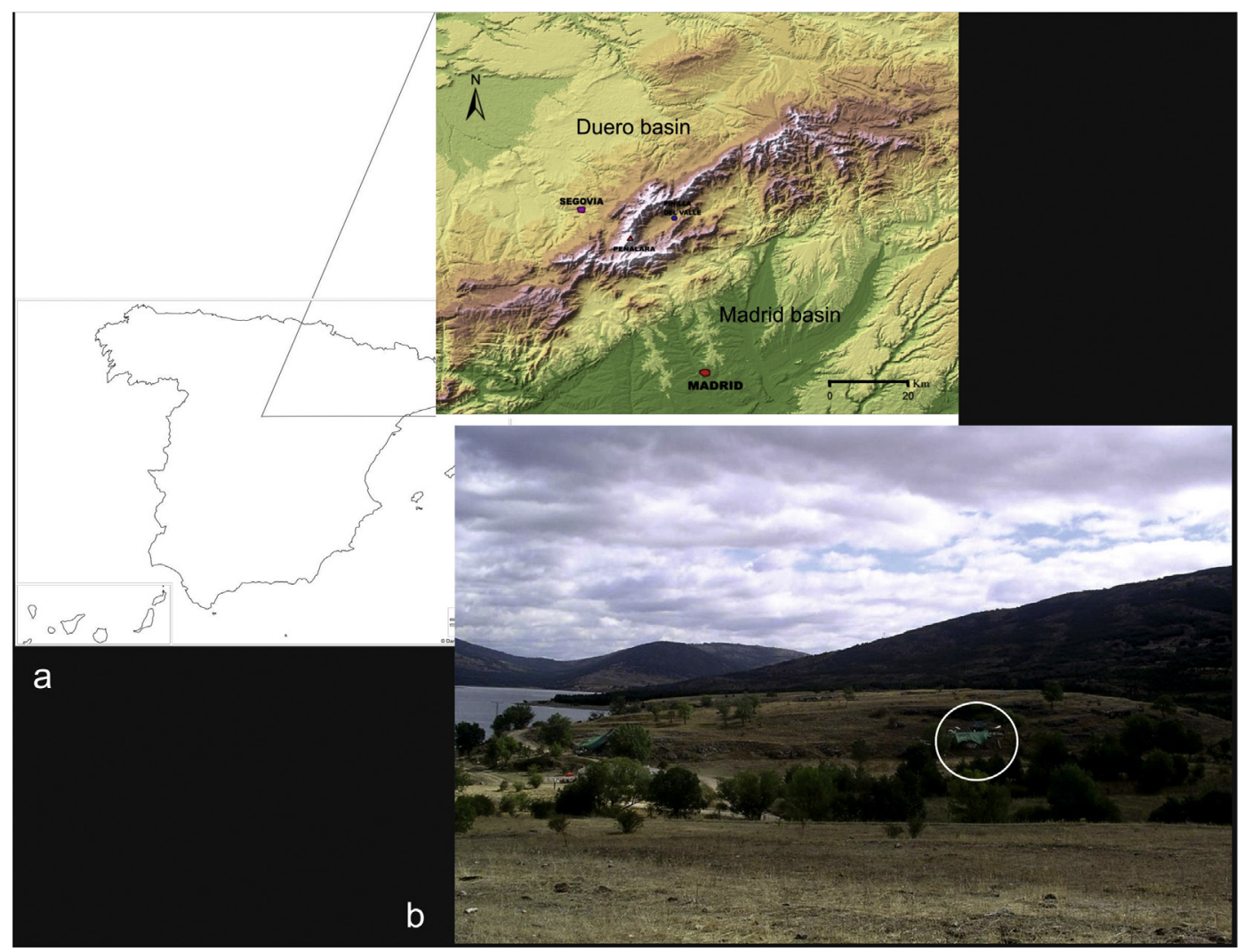

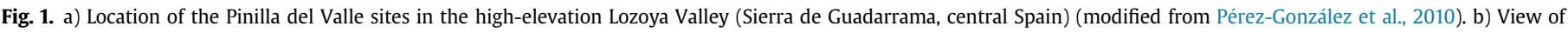
Calvero de la Higuera (Pinilla del Valle). The white circle marks the location of Navalmaíllo Rock-shelter site. 


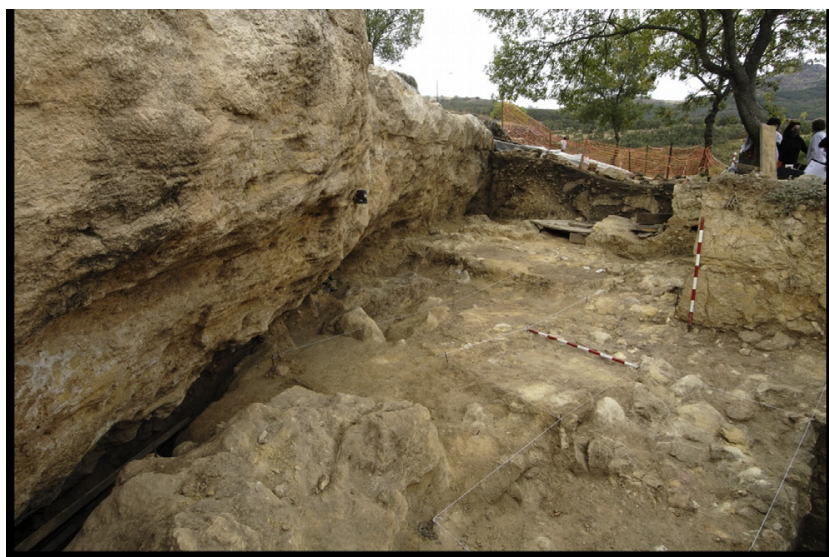

a

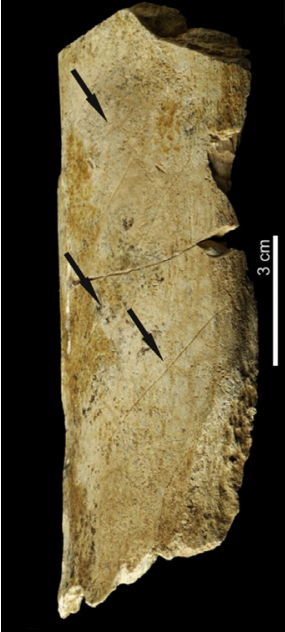

b
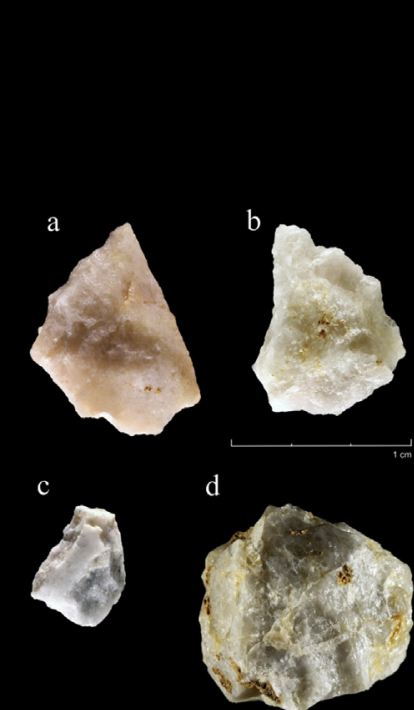

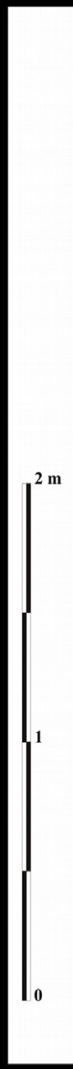

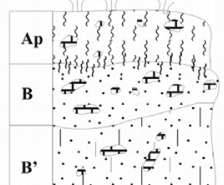

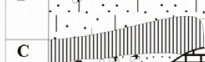

E
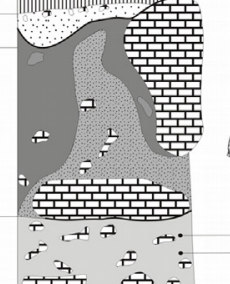

(1)

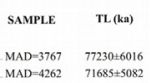

$\mathbf{F}$

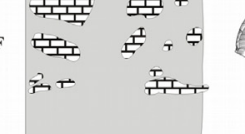

1.

LEGEND

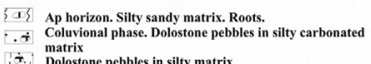

IIIIIIII Silty clay

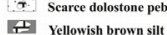

II$$
+
$$$$
\text { FL }
$$$$
\text { hijected brown sandy clay with dolostone pebbles. Abundar }
$$
injected archaeological remains Brown sandy clay with
archaeological remains
Dolostone blocks

IIIIIIII Clay

Crossed estratification

Main disconformitics

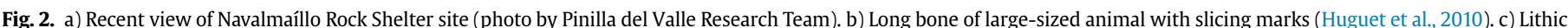

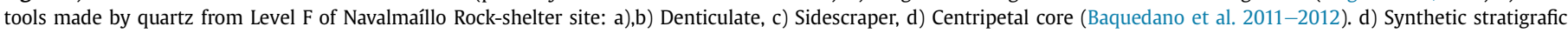
column of Navalmaíllo Rock Shelter TL age estimates for level F are shown.

to $15 \mathrm{~cm}$ along the major axis, all within a pale brown, siltysandy matrix (10YR 5/2). The depth of these coluvionary facies reaches $1 \mathrm{~m}$ in some sectors.

- The deeper levels are formed by Level C, a grey silty-clayey horizon (C) 10-15 cm thick without clasts, and Levels D and E, some $0.5-0.8 \mathrm{~m}$ thick, formed from gravel and blocks, some measuring $1 \mathrm{~m}$ along the major axis. Sometimes Levels D and E show strong alteration due to the falling of carbonate rocks from the rock shelter ceiling. The spaces between the blocks have become filled with fauna- and lithic industry-containing sediments from the underlying Level $\mathrm{F}$.

- Level F lies on at least $1.80 \mathrm{~m}$ of fine siliceous gravel, sand, granular material and sandy mud, together representing a fluvial terrace. Two thermoluminescence (TL) dates are available for Level F: $71.6 \pm 5.0$ and $77.2 \pm 6.0 \mathrm{ka}$. It therefore belongs to MIS 5a or the start of MIS 4 (Pérez-González et al., 2010)

Anthropic activity was intense at the Navalmaíllo Rock Shelter, which contains evidence of lithic industry, hearths and taphonomic signs of the human consumption of large mammals (Fig. 2), which together suggest Level F represents a Neanderthal camp. Very few remains of large carnivorous animals have been found at the site, nor are there many signs that such animals consumed large mammals there. Numerous fragments of coprolites belonging to small carnivores, however, have been collected, and the remains of macro- and micromammals including those of the genus Lepus, have been found in Level F (Baquedano et al., 2010, 2011/2012, 2014; Huguet et al., 2010; Arsuaga et al., 2011; Márquez Mora et al., 2013).

\section{Sample and methods}

The recovery of faunal remains from the Navalmaillo Rock Shelter took place over several stages between 2003 and 2007. During the systematic excavation of Level $\mathrm{F}$, the coordinates of all large anatomically identifiable skeletal remains and those unidentifiable but larger than $2 \mathrm{~cm}$ in length were noted. The accompanying sediment was sieved under a jet of water at moderate pressure through $1 \mathrm{~cm}, 2 \mathrm{~mm}$ and $0.6 \mathrm{~mm}$ meshes to collect small bone remains, the remains of microvertebrates, and lithic industry fragments. The remains of lagomorphs were then 
identified in the different fractions using the lagomorph reference collection of the Museo Arqueológico Regional de la Comunidad de Madrid (MAR) and following the taxonomic criteria of Callou (1997).

The total number of lagomorph remains $(\mathrm{NR}=704)$ was recorded and the minimum number of individuals (MNI) and the minimum number of elements (MNE) calculated (Bunn and Kroll, 1986; Bunn et al., 1988; Cruz Uribe, 1988). As an aid to the identification of the predators responsible for the accumulations, different criteria used in actualistic studies (Dodson and Wexlar, 1979; Andrews, 1990; Fernandez-Jalvo, 1992; Pérez-Ripoll, 1992, 2001, 2005/2006; Lyman, 1994; Fernández-Jalvo and Andrews, 2003; Gardeisen and Valenzuela, 2004; Jones, 2006; Lloveras et al., 2008a, 2008b, 2009a, 2010, 2012a; Gardeisen, 2012) were applied.

\subsection{Anatomical representation}

The representation of different body parts was determined by calculating Dodson and Wexlar indices (1979). These indices were then used to calculate those proposed by Andrews (1990) as modified by Lloveras et al. (2008a):

PCRT/CR - the total number of postcranial elements (humeri, radii, ulnae, femora, tibiae, patellae, scapulae, innominate, metacarpals, metatarsals, phalanges, carpals/tarsals, vertebrae and ribs) over the number of cranial elements (maxillae and mandibles).

PCRAP/CR - the number of appendicular bones (long bones, scapulae, innominate, patellae, metapodials, carpals, tarsals and phalanges) over the number of cranial elements.

PCRLB/CR - the number of postcranial long bones (humerus, radius, femur, ulna and tibia) over the number of cranial elements.

AUT/ZE - the number of autopodial bones (metapodials, carpals, tarsals and phalanges) over the number of zygopodium plus stylopodium bones (tibia, radius, ulna, humerus, femur and patella).

$\mathrm{Z} / \mathrm{E}$ - the number of zygopodium bones over the number of stylopodium bones.

$\mathrm{AN} / \mathrm{PO}$ - the number of humeri, radii, ulnae and metacarpals over the number of femurs, tibiae and metatarsals.

\subsection{Fragmentation}

The degree of fragmentation of the bone sample was determined following the method developed by Lloveras et al. (2008a). Using $\mathrm{R}$ software (www.r-project.org), principal components analysis (PCA) was performed to compare the obtained fragmentation patterns (mean value of complete long bones, mean value of complete elements, maximum and minimum length, average and \% of remains smaller than $10 \mathrm{~mm}$ ) with those reported for the Eagle Owl, Fox, Spanish Imperial Eagle and Iberian Lynx in the actualistic studies of Lloveras et al. (2008a, 2008b, 2009a, 2010, 2012a).

\subsection{Age}

Lloveras et al. (2012b) noted the importance of this variable in taphonomic studies. On some occasions, it has provided information on the seasonality of an accumulation. The age of the lagomorphs at the time of their death was determined by the degree of fusion at the joints between the long bones (following the criteria of Gardeisen, 2012; Jones, 2006; Gardeisen and Valenzuela, 2004) and by examining the tooth remains according to the criteria of Yardin (1968) and Michaeli et al. (1980).

\subsection{Taphonomic modifications}

Using a Leica SE6 binocular microscope, or a FEI Quanta 200 Environmental Scanning Electron Microscope (ESEM) when required, the surfaces of the remains were examined for taphonomic evidence of non-human predator (tooth, claw and beak marks following Lloveras et al., 2008a, 2008b, 2009a, 2012a) and human consumption (Lloveras et al., 2009b; Pérez-Ripoll, 1992, 2001, 2005/2006). The number of bone fragments showing each of these markings was recorded. The fragments were also examined for diagenetic alterations that might have obfuscated or mimicked these markings, making their interpretation more complex. The post-depositional surface damage considered in this study was trampling (Lyman, 1994) weathering (Andrews, 1990; Fernández-Jalvo, 1992; Fernández-Jalvo and Andrews, 1992), abrasions and roots marks (Fernández-Jalvo, 1992; Lyman, 1994) and manganese oxide discoloration (Courty et al., 1989). Signs of abrasion were scored on the proposed scales using the method of Cáceres (2002). Rounding and polishing caused by water abrasion was distinguished from that caused by digestion via the striation marks accompanying the former and the corrosion of the bone caused by the latter (Andrews, 1990; Fernández-Jalvo, 1992; Fernández-Jalvo and Andrews, 2003). The degree of digestion of the bone fragments was determined following the method of Andrews (1990) as modified by Lloveras et al. (2008a), recording results on the proposed 5-point scale: $0=$ no markings; $1=$ light digestion, 2 = moderate digestion, 3 = strong digestion, and $4=$ extreme digestion.

\subsection{Identification of coprolite fragments}

Potential coprolite fragments recognised by visual inspection (with the naked eye) were subjected to X-ray energy dispersion spectroscopy (X-EDS) by way of confirmation, comparing their composition to that of the bone fragments to which they were attached. Coprolites are made of the evacuated bone paste that forms during carnivore digestion following the consumption of skeletal material. They therefore have the same composition as bone (calcium phosphate and carbonate). The detection of calcium and phosphorus in chemical analyses confirmed coprolite identifications. The presence of coprolites is a criterion used in the identification of hyaena dens (Villa et al., 2004). The coprolites of both small and large carnivores have large internal hollows, and have mostly the same external and internal characteristics. However, those of small carnivores tend to be smaller, elliptical or oval in shape, and more porous than those, say, those of hyaenas, and sometimes contain lagomorph remains (Arribas, 1994). The confirmation of coprolite remains adhered to the present lagomorph remains clearly suggests they were accumulated at the site by a carnivore.

\section{Results}

A total of 704 lagomorph bone fragments were recovered, 64 of which clearly belonged to rabbits (Oryctolagus cuniculus), and 1 of which clearly belonged to a hare (Lepus sp.). The MNE was 577, and the MNI derived from the number of lower, left, p3 and d3 (deciduous or adult) was 24 . While 18 individuals (75\%) had their adult teeth, 6 (25\%) still had their deciduous teeth (Fig. 3). As few long bones were found, the determination of age at death was largely dependent on the examination of the teeth.

\subsection{Anatomical representation}

The relative abundance of skeletal elements value was $13.31 \%$. The most common elements were teeth (both incisors and molars); the least common were vertebrae, ribs, carpals and tarsals (Table 1). 
Table 1

List of lagomorph skeletal elements; NR: number of remains; MNE: minimum number of elements; IRA: index of relative abundance.

\begin{tabular}{|c|c|c|c|c|}
\hline Skeletal element & NR & NR\% & MNE & IRA\% \\
\hline Mandibles & 2 & $0.28 \%$ & 2 & $4.17 \%$ \\
\hline Maxillae & 2 & $0.28 \%$ & 2 & $4.17 \%$ \\
\hline Incisors & 56 & $10.51 \%$ & 46 & $31.94 \%$ \\
\hline Upper molariform teeth & 132 & $17.32 \%$ & 131 & $45.49 \%$ \\
\hline Lower molariform teeth & 125 & $15.76 \%$ & 119 & $49.58 \%$ \\
\hline Humerus & 12 & $1.70 \%$ & 8 & $16.60 \%$ \\
\hline Radius & 18 & $2.56 \%$ & 5 & $10.41 \%$ \\
\hline Ulna & 2 & $0.28 \%$ & 2 & $4.17 \%$ \\
\hline Femur & 8 & $1.14 \%$ & 8 & $16.60 \%$ \\
\hline Tibia & 3 & $0.43 \%$ & 2 & $4.17 \%$ \\
\hline Patella & 2 & $0.28 \%$ & 2 & $4.17 \%$ \\
\hline Scapula & 4 & $0.57 \%$ & 4 & $8.30 \%$ \\
\hline Innominate & 3 & $0.43 \%$ & 3 & $6.25 \%$ \\
\hline Metacarpals & 15 & $2.13 \%$ & 13 & $6.78 \%$ \\
\hline Metatarsals & 36 & $5.11 \%$ & 23 & $11.98 \%$ \\
\hline Phalanges $1 / 2$ & 143 & $20.31 \%$ & 125 & $15.32 \%$ \\
\hline Phalanges 3 & 52 & $7.39 \%$ & 52 & $12.03 \%$ \\
\hline Calcaneus & 9 & $1.28 \%$ & 7 & $14.58 \%$ \\
\hline Astragalus & 20 & $2.84 \%$ & 11 & $22.92 \%$ \\
\hline Carpal/Tarsal & 10 & $1.42 \%$ & 10 & $2.98 \%$ \\
\hline Vertebrae & 1 & $0.14 \%$ & 1 & $0.17 \%$ \\
\hline Ribs & 1 & $0.14 \%$ & 1 & $0.17 \%$ \\
\hline Total & $\begin{array}{l}656+17 \text { indet. } \\
\text { teeth }+31 \text { indet. } \\
\text { metapodials }=704\end{array}$ & & 577 & $13.31 \%$ \\
\hline
\end{tabular}

Table 2 shows the results for the PCRT/CR, PCRAP/CR, PCRLB/CR, AUT/ZE, Z/E and AN/PO indices. Data for the first three indices indicate a greater representation of cranial than postcranial elements; those for the AUT/ZE index indicate there was a similar number of autopodial and zygopodial + stylopodial elements; those for the $\mathrm{Z} / \mathrm{E}$ index indicate that there were more zygopodial than stylopodial elements; and the AN/PO index results indicate that hindlimb bones were more abundant than forelimb bones. However, $38 \%$ of the metapodial elements were left out of the calculations because they could not be identified as belonging to one or other such limb.

Table 2

Proportions of anatomical elements. PCRT = Post craneal elements; $\mathrm{CR}=$ Craneal elements; PCRAP = Postcraneal apendicular elements; PCRLB = Postcraneal Long Bones; AUT = Autopodial bones; ZE = Zygopodium bones; $\mathrm{E}=$ Stylopodium bones.

\begin{tabular}{ll}
\hline Index & Value \\
\hline PCRT/CR & 18.2 \\
PCRAP/CR & 31.9 \\
PCRLB/CR & 26.7 \\
AUT/ZE & 99.1 \\
Z/E & 37.5 \\
AN/PO & 63.6 \\
\hline
\end{tabular}

\subsection{Fragmentation}

The mean value of complete elements was $31.8 \mathrm{~mm}$ (range 1-36 mm) (Table 3). Nearly $70 \%$ of the samples were under $10 \mathrm{~mm}$ in length. Only $31.8 \%$ of the bones recovered were complete; these were always either phalanges, metacarpals, metatarsals, carpals or tarsals. Surprisingly, only $5.8 \%$ of the teeth collected showed no sign of fragmentation. No complete long bones were found, nor were any bones found in their anatomical positions.

Table 3

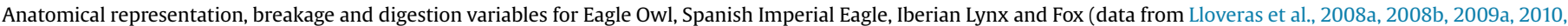
2012a) and the Navalmaíllo Rock Shelter sample.

\begin{tabular}{|c|c|c|c|c|c|c|c|}
\hline \multirow[b]{2}{*}{ Origin } & \multicolumn{2}{|c|}{ Bubo bubo (Eagle Owl) } & \multirow{2}{*}{$\begin{array}{l}\text { Aquila adalberti } \\
\text { (Spanish Imperial } \\
\text { Eagle) } \\
\text { Pellet }\end{array}$} & \multirow{2}{*}{$\begin{array}{l}\text { Lynx pardinus } \\
\text { (Iberian Lynx) }\end{array}$} & \multicolumn{2}{|l|}{ Vulpes vulpes (Fox) } & \multirow{2}{*}{$\begin{array}{l}\text { Navalmaíllo } \\
\text { Rock Shelter } \\
-\end{array}$} \\
\hline & Nest & Nest & & & Scat & Not ingested & \\
\hline RA $>$ values & $\begin{array}{l}\text { Patella-Calcaneus- } \\
\text { Innominate-Femur }\end{array}$ & $\begin{array}{l}\text { Calcaneus- } \\
\text { Innominate- } \\
\text { Tibia-Metatarsal }\end{array}$ & $\begin{array}{l}\text { Phalange 3-Upper } \\
\text { Molar-Tibia }\end{array}$ & $\begin{array}{l}\text { Mandible-Teeth- } \\
\text { Craneal }\end{array}$ & $\begin{array}{l}\text { Long Bones- } \\
\text { Scapula }\end{array}$ & $\begin{array}{l}\text { Metatarsal- } \\
\text { Calcaneus- } \\
\text { Astragalus-Tibia }\end{array}$ & $\begin{array}{l}\text { Molariform } \\
\text { teeth-Incisive }\end{array}$ \\
\hline $\mathrm{RA}<$ values & $\begin{array}{l}\text { Metacarpal-Carpal/ } \\
\text { Tarsal }\end{array}$ & $\begin{array}{l}\text { Radio-Carpal/Tarsal- } \\
\text { Metacarpal }\end{array}$ & $\begin{array}{l}\text { Rib -Femur-Radio- } \\
\text { Vertebrae }\end{array}$ & $\begin{array}{l}\text { Carpal/tarsal- } \\
\text { Vertebrae-Rib }\end{array}$ & $\begin{array}{l}\text { Metacarpal- } \\
\text { Innominate- } \\
\text { Astragalus-Patella }\end{array}$ & $\begin{array}{l}\text { Skull-Scapula- } \\
\text { Rib-Innominate }\end{array}$ & $\begin{array}{l}\text { Vertebrae-Rib } \\
\text { Carpal/Tarsal }\end{array}$ \\
\hline PCRLB/CR & + postcranial & + postcranial & + cranial & + cranial & + postcranial & + postcranial & + cranial \\
\hline $\mathrm{P} / \mathrm{D}$ & + proximal & + proximal & + distal & + proximal & + proximal & + distal & $=$ \\
\hline $\begin{array}{l}\mathrm{AN} / \mathrm{PO} \\
\% \text { Complete elements }\end{array}$ & + hindlimb & + hindlimb & + hindlimb & + forelimb & $=$ & + hindlimb & + hindlimb \\
\hline $\begin{array}{l}\text { Mean value } \\
\text { long bones }\end{array}$ & 14.6 & 10.8 & 0 & 2.5 & 0 & 5.9 & 0 \\
\hline $\begin{array}{l}\text { Mean value total } \\
\text { Length (in } \mathrm{mm} \text { ) }\end{array}$ & 53.9 & 45.9 & 27 & 43 & 8 & 92.3 & 31.8 \\
\hline Maximum & 86.3 & 90.0 & 36.1 & 30.1 & 22.6 & - & 36 \\
\hline Minimum & 2.3 & 2.5 & 1.8 & 1.1 & 2.6 & - & 1 \\
\hline Average & 14.07 & 14.78 & 8.36 & 7.1 & 9.13 & - & 3.4 \\
\hline $\begin{array}{l}\%<10 \mathrm{~mm} . \\
\text { Digestion }\end{array}$ & 49 & 40 & 73 & 80 & 63 & - & 67.6 \\
\hline $\begin{array}{r}\text { \% Digested } \\
\text { remains }\end{array}$ & 68.8 & 65.6 & 98 & 97.2 & 100 & - & 25.2 \\
\hline $\begin{array}{l}\text { \% Digested } \\
\text { long bones } \\
\text { Intensity }\end{array}$ & 88.9 & 83.9 & 100 & 100 & 100 & - & 39.5 \\
\hline Null & 31.2 & 34.4 & 2.0 & 2.8 & 0 & - & 74.8 \\
\hline Light & 40.2 & 40.2 & 18.2 & 12.0 & 1 & - & 11.1 \\
\hline Moderate & 19.8 & 19.8 & 46.8 & 22.0 & 26.7 & - & 10.1 \\
\hline Heavy & 8.0 & 5.3 & 27.4 & 43.8 & 43.5 & - & 3.2 \\
\hline Extreme & 0.7 & 0.15 & 5.6 & 19.3 & 28.7 & - & 0.3 \\
\hline Teeth marks \% & - & - & - & 0.26 & 1.7 & 9.5 & - \\
\hline Beak marks \% & 2.0 & 1.34 & 0.5 & - & - & - & - \\
\hline
\end{tabular}




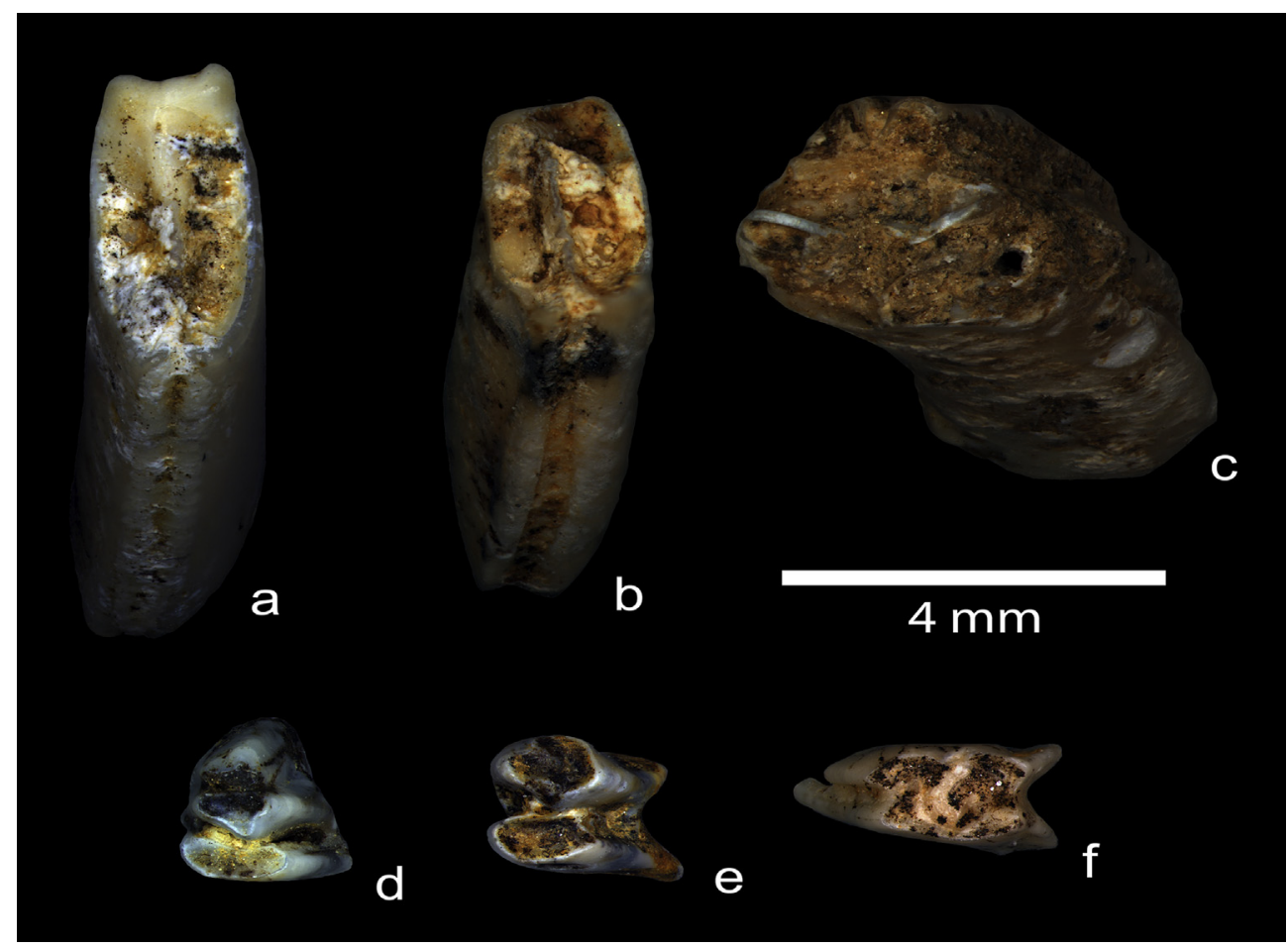

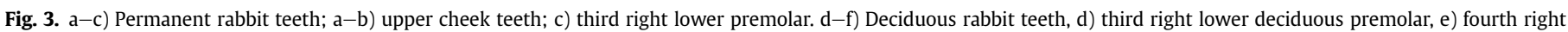
lower deciduous premolar, f) upper left deciduous premolar.

PCA returned two axes that explained $94 \%$ of the variance in the bone fragmentation pattern (Fig. 4) (Table 4). Axis 1 was composed of a set of four variables, each with a loading score of over $90 \%$ : percentage of complete long bones, maximum length recorded, the average length of all the bone fragments, and the percentage of the bone sample under $10 \mathrm{~mm}$ in length. Axis 2 was composed of just one variable (mean value of complete elements) with a loading score of $90 \%$. Axis 1 separated the bone fragmentation caused by the Eagle Owl (Bubo) from that caused by all other predators. Axis 2 separated the bone fragmentation patterns caused by foxes (Vulpes) and the Spanish Imperial Eagle (Aquila) from that associated with the Iberian Lynx and the pattern recorded at the site.

Table 4

Loading scores of the correlation values and their significance of the PCA for breakage variables.

\begin{tabular}{lll}
\hline & Correlation & p.value \\
\hline Dim.1 & & \\
Average length of all bone fragments & 0.9293800 & 0.02228799 \\
Mean value complete long bones & 0.9161160 & 0.02879459 \\
Maximum length & 0.9053877 & 0.03443452 \\
\% of remains smaller than $10 \mathrm{~mm}$ & -0.9172692 & 0.02820789 \\
Dim.2 & & \\
Mean value complete elements & 0.8997396 & 0.03753068
\end{tabular}

\subsection{Taphonomic modifications}

No modifications caused by teeth, claws or beaks, or by human cutting tools, were recognised. Digestive corrosion was identified on $25 \%$ of the studied fragments, with more bones (38\%) than teeth (10) showing such alteration. All degrees of digestion were recorded, although degrees 1 and 2 were the most common (Table 3, Fig. 5).
On average, $70 \%$ of the bone/tooth fragments showed rounding caused by water abrasion. More than $90 \%$ of the postcranial elements had been rounded in this way. Only $60 \%$ of the teeth showed this alteration. The most common degree of rounding both in cranial and postcranial elements was R1. Over $50 \%$ of the fragments showed signs of polishing, especially the postcranial elements (>90\%). The most common degree of polishing recorded was P1, followed by a very small representation of P2. Some $85 \%$ of the fragments showed signs of both rounding and polishing (Fig. 6).

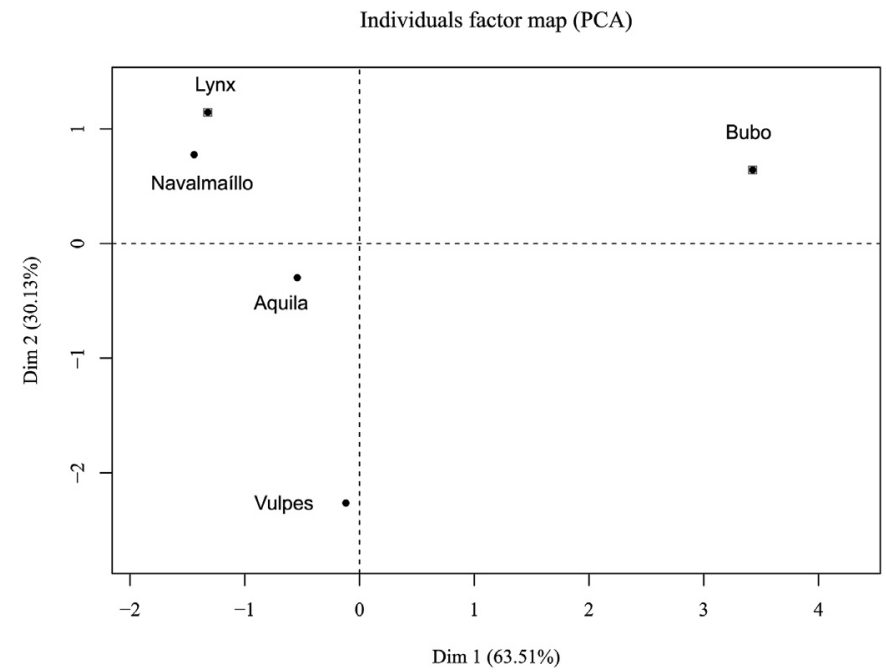

Fig. 4. Spatial distribution of breakage patterns for the Eagle Owl (Bubo), Spanish Imperial Eagle (Aquila), Iberian Lynx (Lynx) and Fox (Vulpes) (data from Lloveras et al., 2008a, 2008b, 2009a, 2010, 2012a, 2012b), and for the Navalmaíllo Rock Shelter remains (Navalmaíllo) according to PCA. 


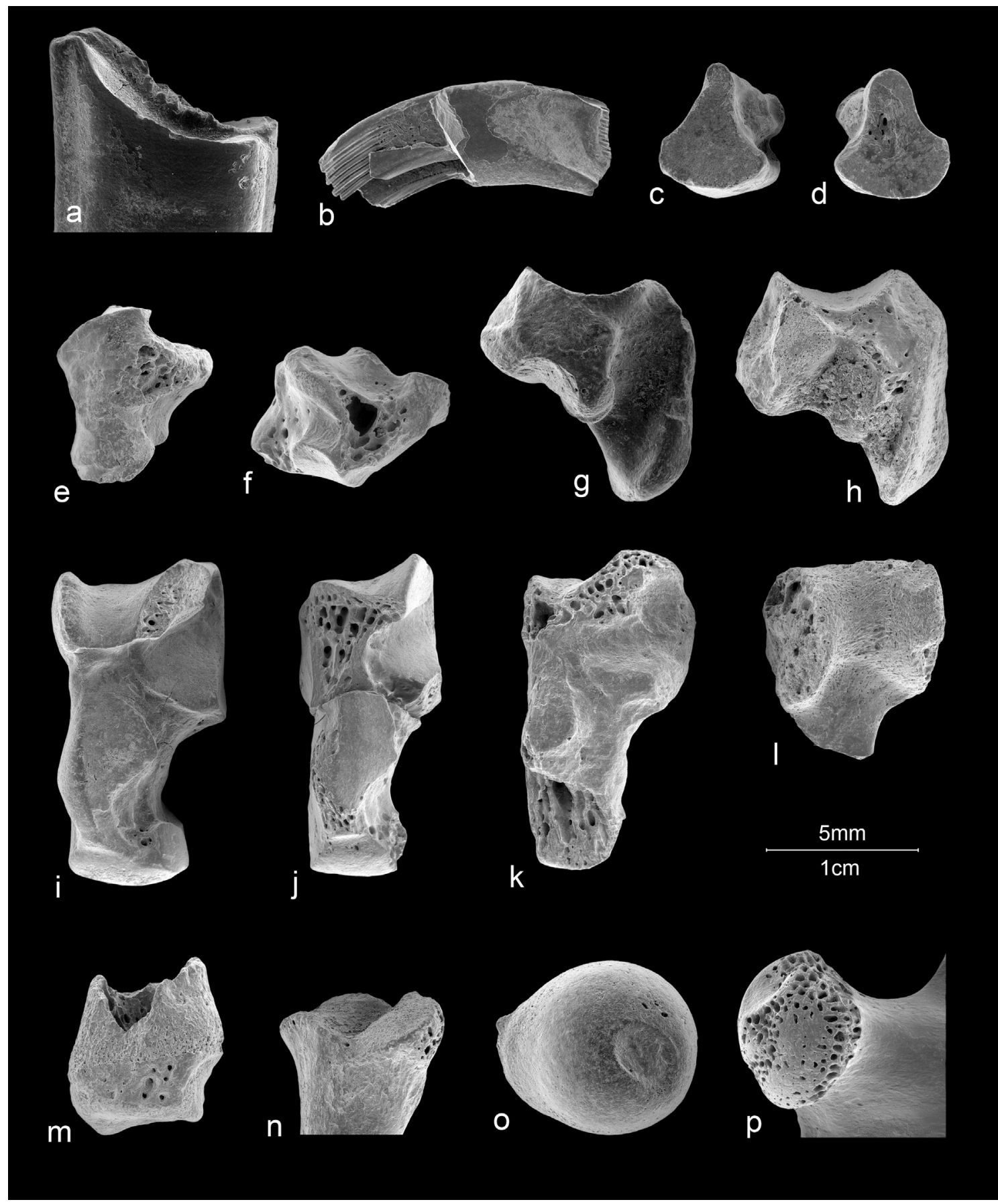

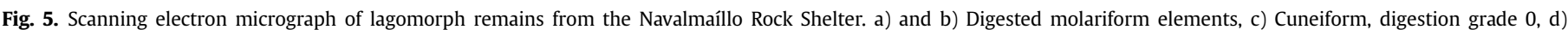

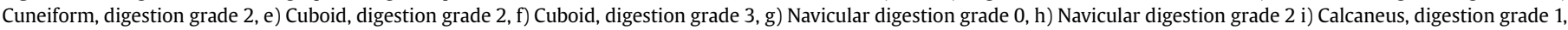

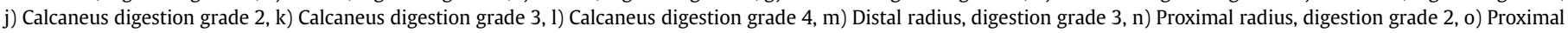
femur, digestion grade 1, p) Proximal femur, digestion grade 2 .

In addition $44 \%$ of the remains showed marks left by roots. Root action was so strong in some cases that the affected bones and teeth were almost unrecognisable (Fig. 7). All the elements inspected showed the presence of manganese oxides: $77 \%$ showed strong staining. No remain showed trampling marks or weathering modifications.

\subsection{Identification of coprolites}

The remains of coprolites were seen adhered to 40 fragments (both bone and tooth). Most were located on the bone or tooth surface and were ivory-coloured. They were compact, but with small hollows produced by internal air bubbles. Their great porosity suggests that they were deposited by a small carnivore. Their identification was confirmed by testing a representative sample of four supposed coprolite fragments (NAV 09, NAV-18, NAV-02 and NAV-59-01) by X-ray EDS. The bones to which these were adhered (samples NAV 08, NAV-19, NAV-01 and NAV-03) were also tested to confirm that their composition was similar. Figs. 8-11 show the results obtained. The similarity of NAV-18, NAV-02 and NAV-59-01 to their respective bone fragments (NAV-19, NAV-01 and NAV-03) confirms their identity. However, a supposed coprolite sample 


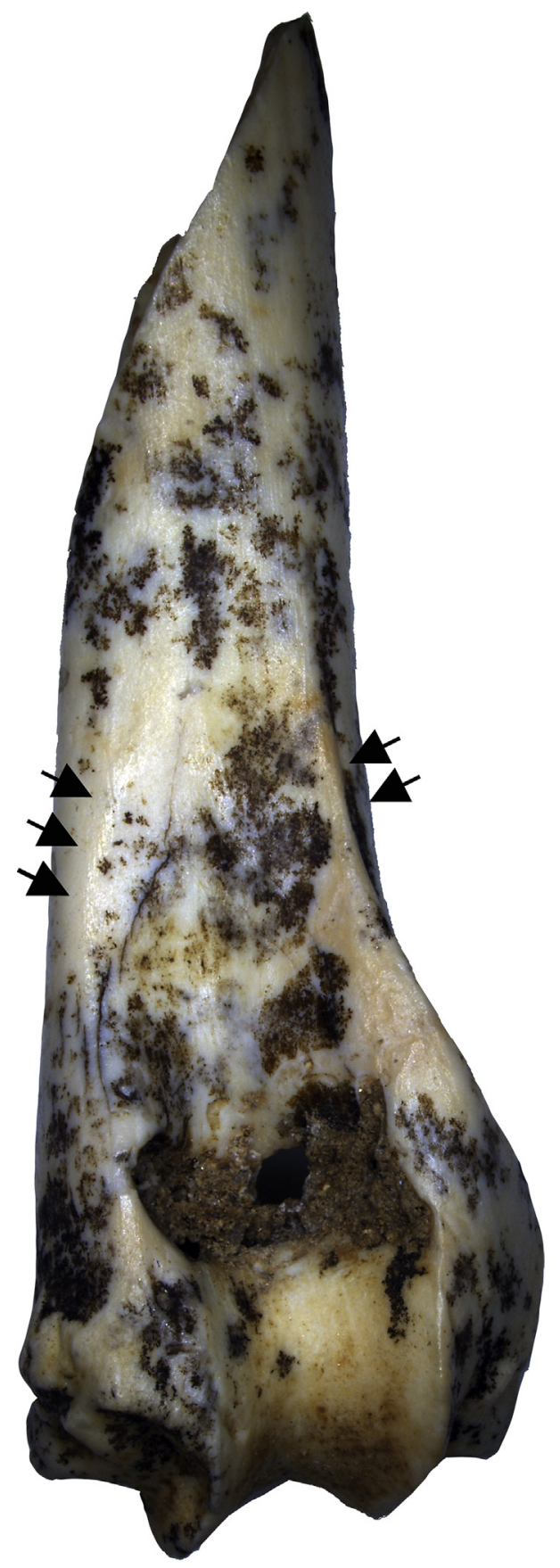

Fig. 6. Distal lagomorph humerus with polishing/rounding due to water action.
(NAV09) was shown not to be a coprolite; it had a greater silicate content than its corresponding bone sample (NAV 08).

\section{Discussion}

Many Pleistocene sites in the Mediterranean Basin contain the remains of lagomorphs that were hunted by humans or animal predators. However, sites dating to before the Upper Palaeolithic contain many fewer examples of such human-hunted remains. Evidence at sites of an age similar to that of the Navalmaíllo Rock Shelter in the Mediterranean Basin (Moscerini and Sant Agostino [Stiner, 1994], Abric Romaní [Cáceres, 1998], Cova 120 [Terradas and Rueda, 1998], Boquete de Zafarraya [Guennouni, 2001; Barroso et al., 2006], Moros de Gabasa I [Blasco Sancho, 1995], Ibex Cave [Fernández-Jalvo and Andrews, 2000] and Foz do Enxarrique [Brugal and Raposo, 1999]) show that lagomorphs were not generally hunted by humans of this time despite their being available. Further, bone assemblages from anthropic sites are dominated by adults (Hockett and Bicho, 2000; Yravedra, 2008). Long bones, mandibles and innominate bones are the most common, and they frequently show clear signs of human manipulation, such as cut marks, peeling, and the marks of human teeth (PérezRipoll, 1992; Hockett and Bicho, 2000; Pérez-Ripoll, 2001; Hockett and Haws, 2002; Pérez-Ripoll, 2005/2006; Yravedra, 2008). Elements showing such markings are, however, absent at the Navalmaíllo Rock Shelter, and the individuals represented are of a wider age range. The absence of anthropic signs suggests the animal responsible for the accumulation of the remains was nonhuman.

The examined remains seem to have been the prey of some predatory animal; they do not appear to represent animals that died in their burrows. They clearly show signs of digestion, no intact skeletons or bones were found in their anatomical positions, and the Dodson and Wexlar indices were low. Thus, these lagomorphs were likely taken by a predator.

Carnivores and raptors were protagonists in the production of the lagomorph fossil record for the Pleistocene (Stiner, 1994; Blasco Sancho, 1995). Signs of strong digestion, and marks left by teeth, claws and beaks, are evidence of animal predator action. Some $25 \%$ of the lagomorph remains at the Navalmaíllo Rock Shelter show signs of strong digestion, but no tooth, claw or beak marks were seen. This, however, is not uncommon (Lloveras et al., 2008a, 2008b, 2009a, 2012a). Further, the relative abundance of skeletal elements, the body part representation results, and the fragmentation of the sample all suggest that an animal predator preyed upon these lagomorphs. Some evidence suggests that the predator responsible was an Iberian Lynx (Table 3). The least common elements found were vertebrae, ribs, and carpals/tarsals, and the most common were teeth. In actualistic studies, Lloveras et al. (2008b) reported such a pattern to be associated with this felid. The PCRT/
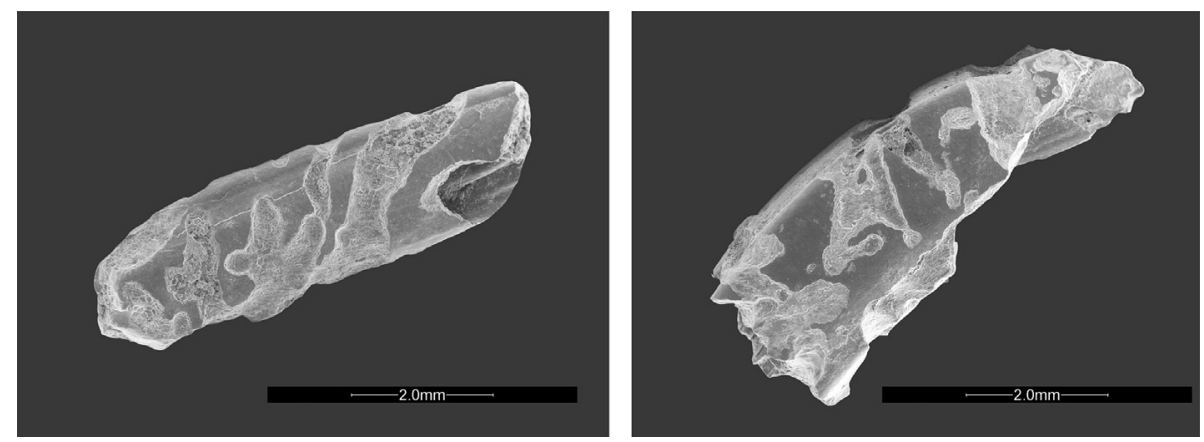

Fig. 7. Scanning electron micrograph of lagomorph molariform elements (with visible root marks) found in Level F at the Navalmaíllo Rock Shelter. 

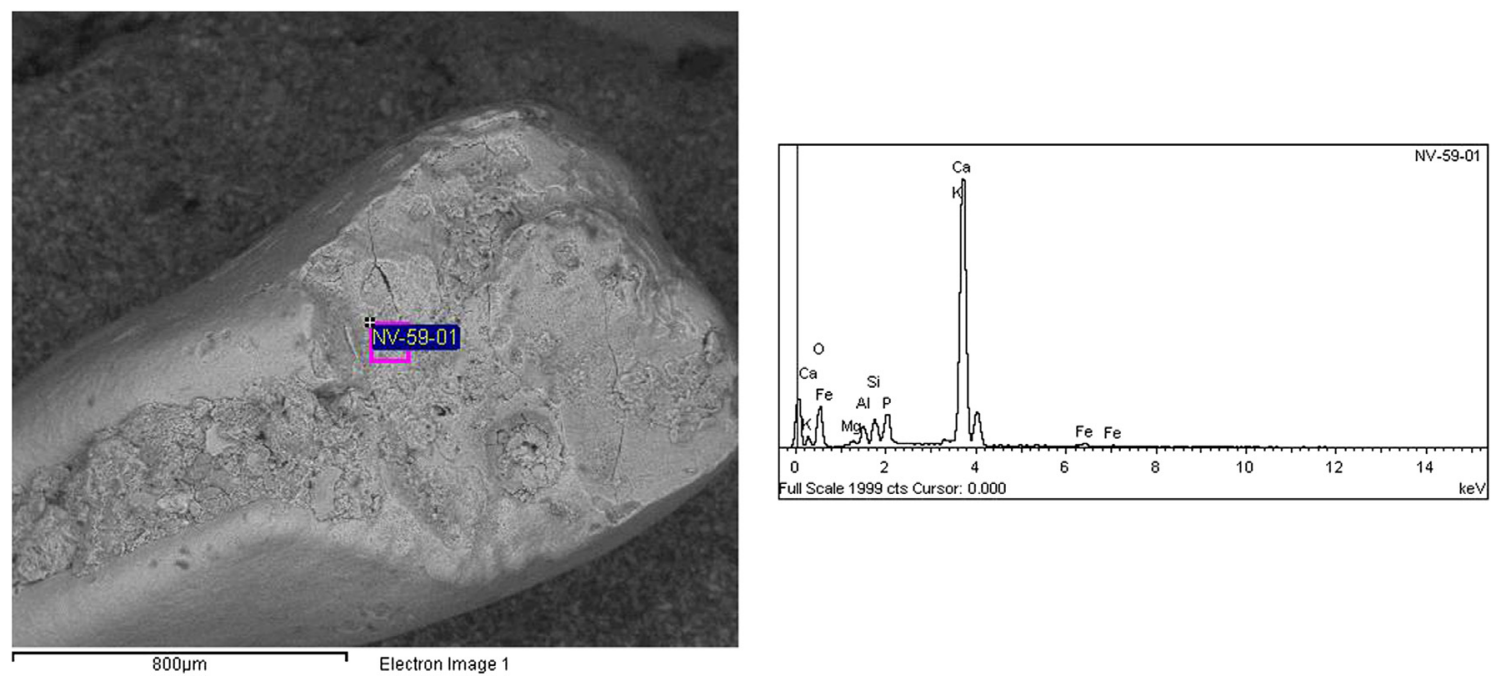

Fig. 8. Scanning electron micrograph of a lagomorph deciduous tooth element, plus chemical analysis of an adhered coprolite (NAV-59-01).

CR, PCRAP/CR and PCRLB/CR indices show cranial skeletal elements to be more common; a pattern associated with the Iberian Lynx (Lloveras et al., 2008b). However, the values of the AUT/ZE, Z/E and $\mathrm{AN} / \mathrm{PO}$ indices are not those that might be expected.

Lloveras et al. (2008a, 2008b, 2009a, 2012a) indicate that the faeces of foxes and lynxes, and the nest litter of Eagle Owls, contain a greater proportion of proximal leg parts (tibia, radius, humerus, femur and patella), while the pellets of the Spanish Imperial Eagle contain more distal parts (metapodials, carpals, tarsals and phalanges). However, in the present remains, the proportion of upper and lower limb parts was similar, making it difficult to identify the predator responsible (Table 3). Nonetheless, hindlimbs were more common than forelimbs. At first sight this would not be expected for lynx faecal remains, in which forelimbs are usually the more common (Lloveras et al., 2008b); normally lynxes do not consume the lower extremes of lagomorph hindlimbs, which remain hanging on the discarded skin and therefore do not pass through the predator's digestive system (Delibes, 1980; Calzada and Palomares, 1996; Lloveras et al., 2008b). Thus, metacarpals - but not metatarsals - are usually seen in lynx faeces. In the present samples, metatarsals were twice as common as metacarpals, suggesting a lynx was not responsible. However, it is important to note that 31 metapodial fragments could not be identified as metatarsals or metacarpals. Thus, it cannot be ruled out that a lynx predated the examined lagomorphs.

Intriguingly, the proportions of the different bone types recorded were quite similar to those that might be expected if the Spanish Imperial Eagle were the predator (Lloveras et al., 2008a). In the regurgitated pellets of modern Spanish Imperial Eagles, lagomorph teeth are very common - as seen in the present sample - as are the third phalange and the tibia (Lloveras et al., 2008a), while the least common remains are the ribs and vertebrae (as seen for the present remains), femur and radius (Table 3). Similarly, the PCRT/CR, PCRAP/CR and PCRLB/CR indices usually reveal these
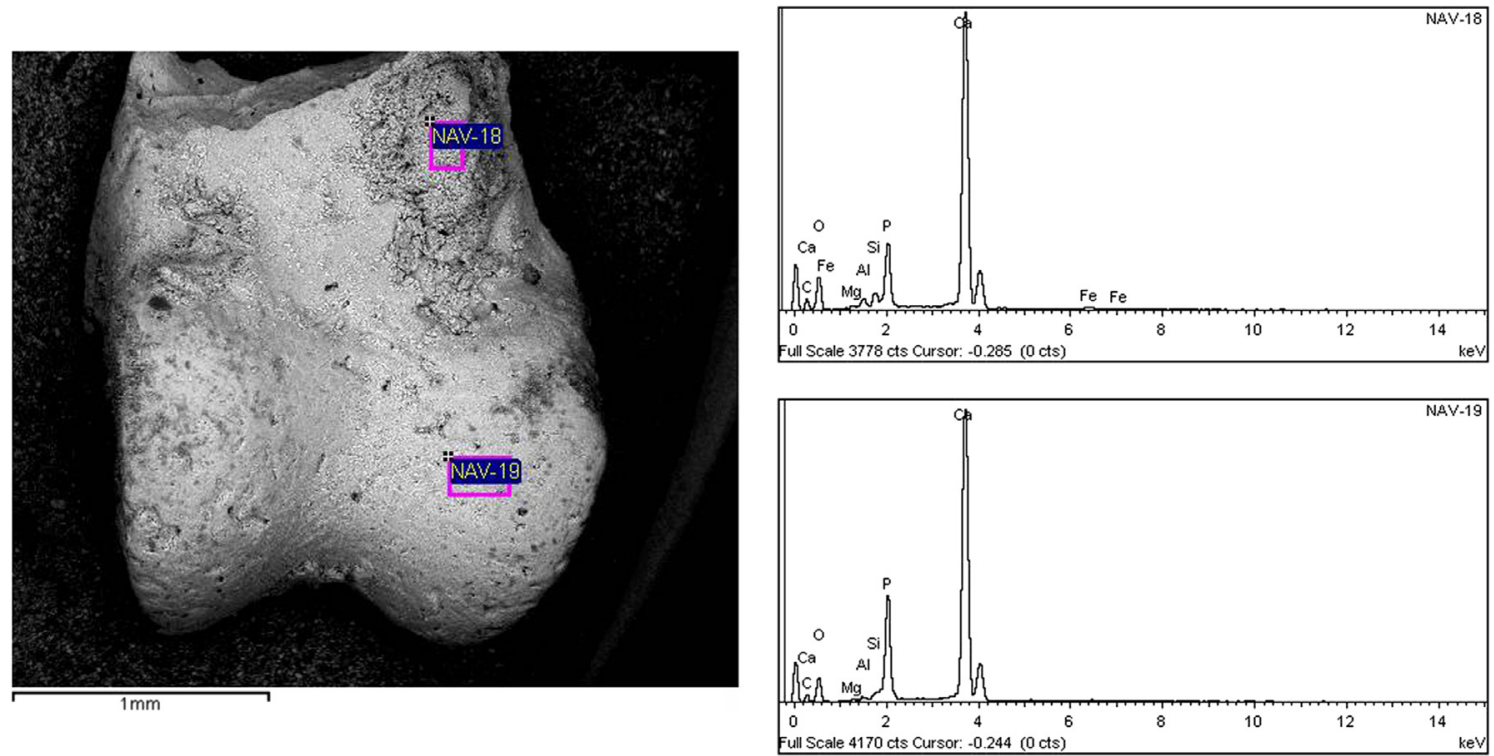

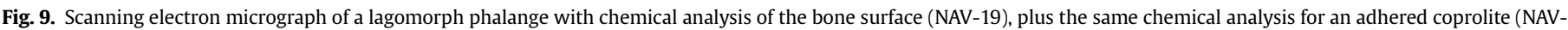
18). 

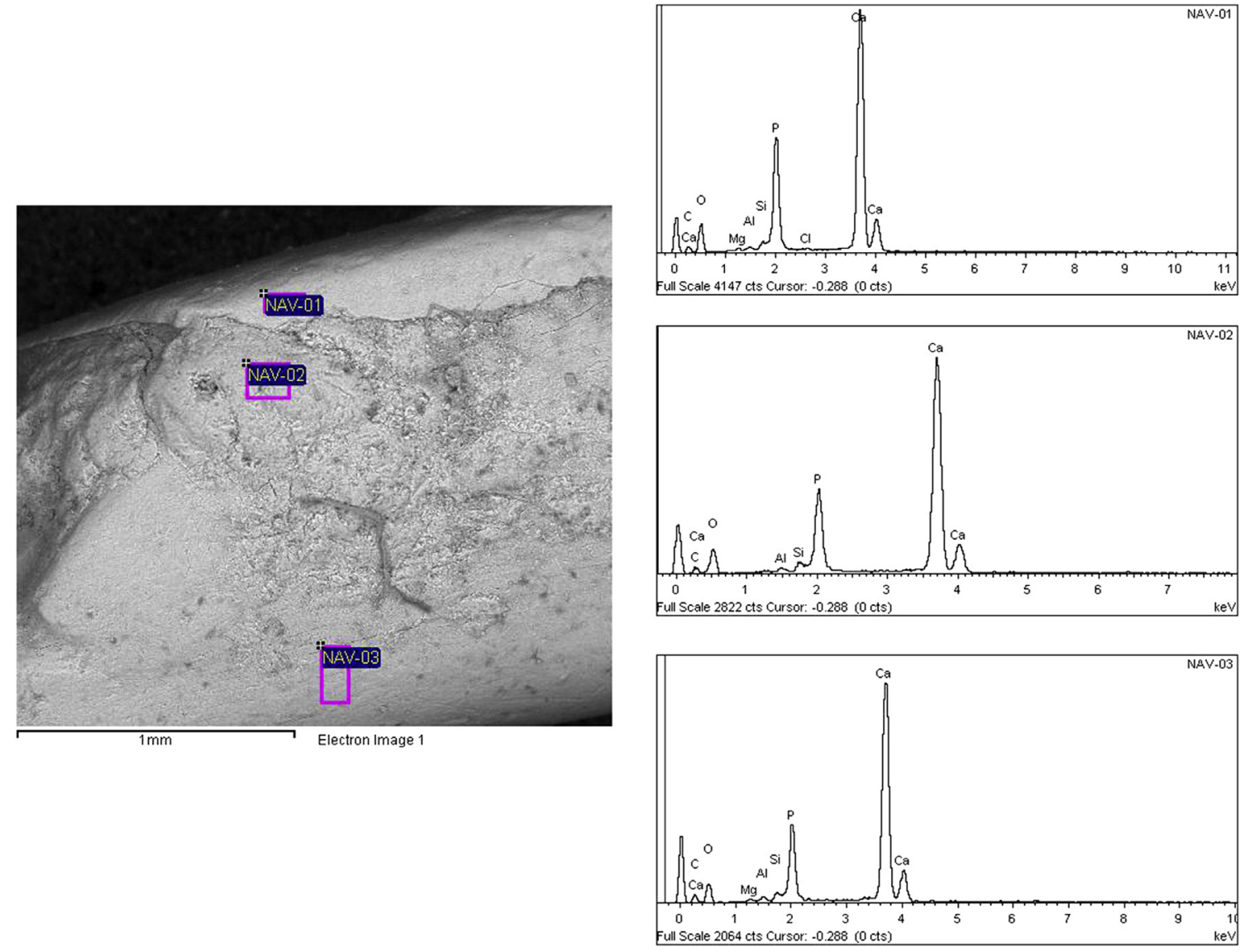

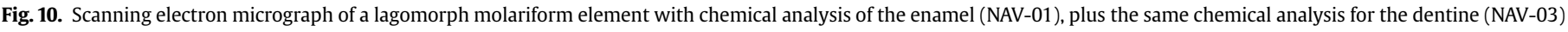
and an adhered coprolite fragment (NAV-02).

pellets to contain a higher proportion of cranial elements, as seen in the present remains. Further, hindlimbs were more common in the present sample, another sign that this eagle species may have been the predator (Lloveras et al., 2008a).

However, the PCA results suggest that most likely predator was, in fact, the Iberian Lynx (Fig. 4). Axis 1 separates the fragmentation patterns for the Eagle Owl from those of the other possible predators recorded by Lloveras et al. (2008a,b, 2009a, 2012a), while Axis 2 separates the pattern for the Iberian Lynx (described by the same authors) plus the pattern recorded for the present sample from that described by the above authors for the Spanish Imperial Eagle and Fox. Thus, suspicion once again falls on the Iberian Lynx as the predator that took the examined lagomorphs.

Comparisons similar to those made above rule out that the examined remains were left by an eagle owl or a fox (Table 3 ). The consumed remains left over by these predators never contain large number of teeth, unlike that seen for the present sample. Neither were the PCRT/CR, PCRAP/CR and PCRLB/CR indices for the studied remains those that would be expected (Lloveras et al., 2008a). The new use of classical taphonomic criteria developed in the present work appears to further support the idea that an Iberian lynx was the predator involved: the presence of deciduous teeth and the confirmation of the presence of coprolite material.

Lloveras et al. (2012b) noted the importance of the age at death of prey animals in taphonomic studies on lagomorphs. The results of previous actualistic studies have shown that the proportion of adult lagomorphs in the remains left over by predators can be very variable, and therefore an unreliable indicator of predator identity. For example, the proportion of adults in the diet of foxes has been recorded to vary from 20\% (Sanchís Serra, 2000) to 87\% (Lloveras et al., 2012a). Further, the mortality among juvenile lagomorphs caused by predators (around 50\%) is equally the work of terrestrial carnivores and birds of prey (Villafuerte and Castro, 2007). Thus, the proportion of adult/juvenile remains cannot indicate the predator responsible. However, in the present work, the predator took infant rabbits - those that have still not left the protection of the burrow. These were identified by the presence of deciduous teeth. Infant rabbits maintain their deciduous teeth for around 27 days before shedding them. When the animal reaches this age the musculature of the chewing system, which develops from that used to suckle, is indistinguishable from that of an adult (Weijs et al., 1989; Langenbach et al., 1992, 2001) and the young rabbits are able to feed for themselves. At this point they receive no further maternal care, and are expelled from the burrow in which they were born (Cowan and Bell, 1986; Villafuerte, 2007). Remains that show deciduous teeth are therefore those of infant rabbits - individuals that could never have been taken from their burrows by a bird of prey and must therefore have been killed by a terrestrial predator. Foxes and Iberian Lynxes dig out rabbit burrows and prey on infant rabbits (Delibes, 1980; Villafuerte and Castro, 2007).

Together, the presence of deciduous teeth and of adhered coprolite material strongly suggests that the predator responsible was a small terrestrial carnivore. The PCA results in particular suggest it was probably an Iberian lynx. The free coprolite fragments detected in the sediments examined also suggest that faeces left elsewhere were washed into the rock shelter. Lynx faeces are cylindrical and normally contain lagomorph bones. They are usually deposited along the edge of tracks, but sometimes in middens 

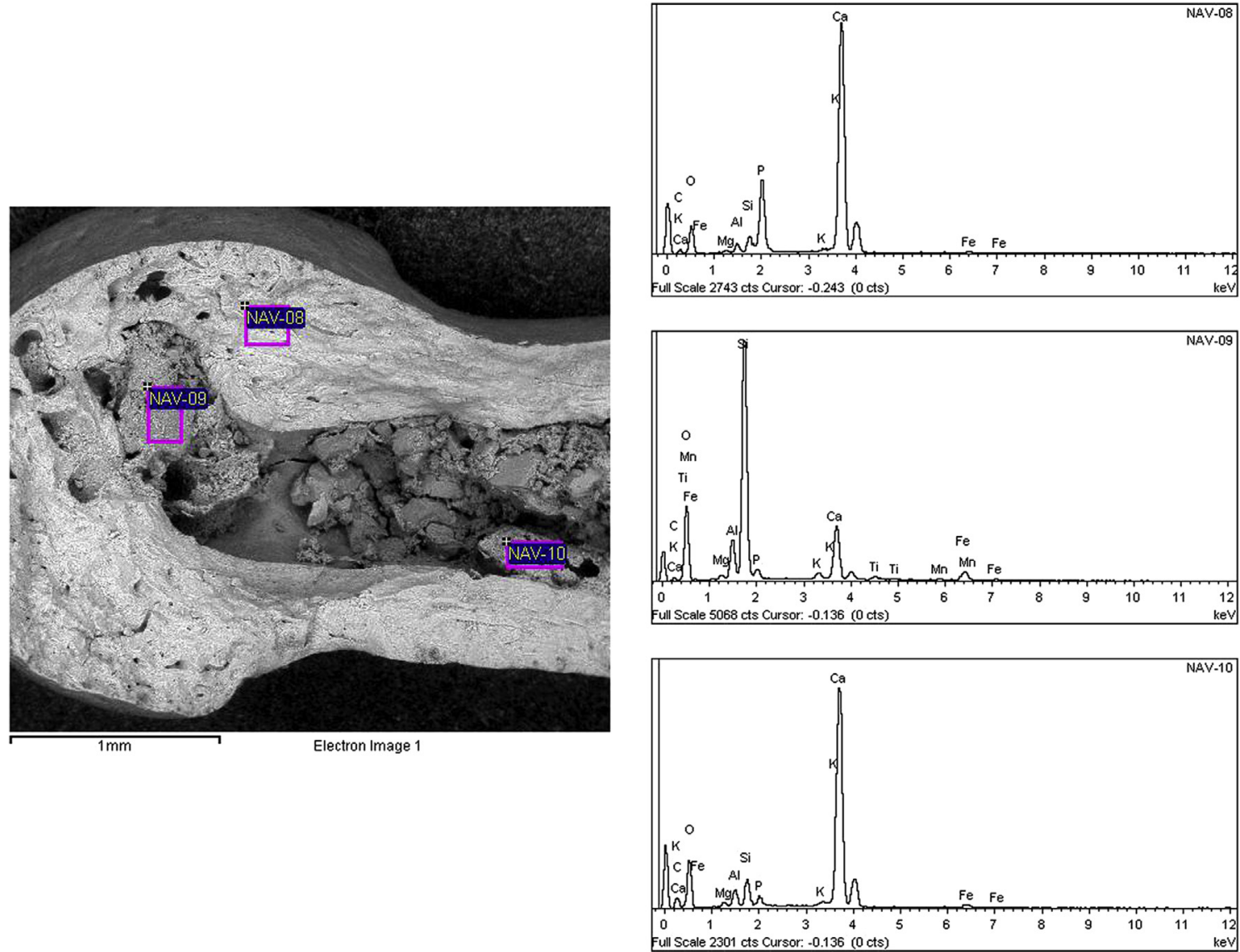

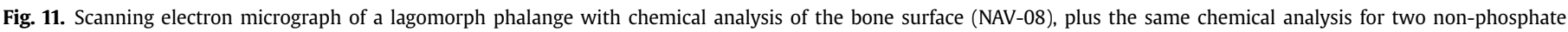
aggregates (NAV-09 and NAV-10).

(San Miguel, 2006). It may be that a lynx midden near or in the Rock Shelter supplied the remains found in Level $\mathrm{F}$ (lagomorph remains were recovered from throughout this level, showing that they accumulated over time). Certainly, lynxes are heavy consumers of lagomorphs, make their lairs in caves, and were widely distributed around the Iberian Peninsula during the Pleistocene (RodríguezHidalgo et al., 2013b).

The lagomorph remains accumulated at the site underwent different biostratinomic and fossildiagenetic processes. The large percentage of fragments showing rounding and polishing suggests them to have been transported in a low energy water current. All the bone fragments examined showed manganese oxide stains. Thus, they must have lain on a wet sedimentary environment. The last stage of fossil diagenesis detected was that caused by plant roots which affected over $40 \%$ of the remains examined. This may have rendered the observation of tooth marks and other marks of digestion more difficult, explaining the small percentage of elements with clear signs.

\section{Conclusions}

The taphonomic study of the lagomorph remains from Level $\mathrm{F}$ at the Navalmaíllo Rock Shelter showed the predator responsible for their accumulation to be non-human. The new use made of classic variables (identification of coprolites adhered to the bones, and the presence of infant lagomorphs), along with the pattern of skeletal representation and the fracturing of the remains, suggests this accumulation was the work of the Iberian Lynx.
The methodological approach based on the lagomorph death ages and the coprolite characterization will help future taphonomic studies on these preys' accumulations from archaeopalaeontological sites. Thus, there will be more data to precisely identify the accumulation agent of the fauna association. Also, this will contribute to recognize if those preys were consumed by human groups or, as the case of the Navalmaillo Rock Shelter, the accumulation was produced by a segregation in prey selection between Neanderthals and small carnivores.

Finally, the Iberian Lynx would appear to be responsible for the present accumulation of lagomorph remains, and may have been so at other sites in the Mediterranean Basin. This should be borne in mind in future taphonomic studies.

\section{Acknowledgements}

The authors are grateful to the Pinilla del Valle excavation team, especially Juan Gómez, and all those who participated in sorting the microfossils in the field laboratory and at the Museo Arqueológico Regional de la Comunidad de Madrid. We also thank Lluís Lloveras and Jordi Nadal for their support, comments and advice, and Antonio Rosas for providing the fox scat samples. Manuel Domínguez-Rodrigo and Antonio Rodríguez-Hidalgo are also thanked for their comments, as is Adrian Burton for editing the manuscript. This research has been conducted within project S2010/BMD-2330 funded by the $\mathrm{I}+\mathrm{D}$ activities programme for research groups of the Consejería de Educación of the Community of Madrid. The economic administration of the project was handled by the 
Fundación General de la Universidad de Alcalá. Mahou-San Miguel S.A. is thanked for sponsorship funding, as are the Parque Natural de Peñalara, the Ayuntamiento de Pinilla del Valle, and Canal de Isabel II Gestion for their collaboration. We finally thank two anonymous reviewers for their comments and suggestions that greatly improved the paper.

\section{References}

Álvarez, M.C., Kaufmann, C.,A., Massigoge, A., Gutiérrez, M.A., Rafuse, D.J., Scheifler, N., González, M., 2012. Bone modification and destruction patterns of leporid carcasses by Geoffroy's cat (Leopardus geoffroyi): an experimental study. Quaternary International 278, 71-80.

Andrews, P., 1990. Olws, Caves and Fossils. British Museum (Natural History), London.

Arribas, A., 1994. Paleontología de macromamíferos del yacimiento mesopleistoceno de Villacastín (Segovia, España). Boletín Geológico y Minero 105 (4), 344-361.

Arsuaga, J.L., Baquedano, E., Pérez-González, A., Sala, M.T.N., García, N., ÁlvarezLao, D., Laplana, C., Huguet, R., Sevilla, P., Blain, H.-A., Quam, R., RuizZapata, M.B., Sala, P., García, M.J.G., Uzquiano, P., Pantoja, A., 2010. El yacimiento arqueopaleontológico del Pleistoceno Superior de la Cueva del Camino en el Calvero de la Higuera (Pinilla del Valle, Madrid). Zona arqueológica 13 ( $1^{\text {a }}$ Reunión de científicos sobre cubiles de hiena (y otros grandes carnívoros) en los yacimientos arqueológicos de la Península Ibérica), pp. 422-442.

Arsuaga, J.L., Baquedano, E., Pérez-González, A., 2011. Neanderthal and carnivore occupations in Pinilla del Valle sites (Community of Madrid, Spain). In: Oosterbeek, L., Fidalgo, C. (Eds.), Proceedings of the XV World Congress of the International Union for Prehistoric and Protohistoric Sciences, British Archaeological Reports International Series. Archaeopress, Oxford, pp. 111-119.

Arsuaga, J.L., Baquedano, E., Pérez-González, A., Sala, N., Quam, R.M., Rodríguez, L., García, R., García, N., Álvarez, D., Laplana, C., Huguet, R., Sevilla, P., Maldonado, E., Blain, H.A., Ruiz-Zapata, B. Sala, P., Gil-García, J., Uzquiano, P. Pantoja, A., Márquez, B., 2012. Understanding the ancient habitats of the lastinterglacial (late MIS 5) Neanderthals of central Iberia: paleoenvironmental and taphonomic evidence from the cueva del Camino (Spain) site. Quaternary International 275, 55-75.

Aura Tortosa, J.E., Villaverde, V., Pérez Ripoll, M., Martínez Valle, R., Guillem Calatayud, P., 2002. Big game and small prey: Paleolithic and Epipaleolithic economy from Valencia (Spain). Journal of Archaeological Method and Theory 9 (3), 215-268.

Baquedano, E., Arsuaga, J.L., Pérez-González, A., 2010. Homínidos y carnívoros: competencia en un mismo nicho ecológico pleistoceno: los yacimientos del Calvero de la Higuera en Pinilla del Valle. In: Actas de las Quintas Jornadas de Patrimonio Arqueológico en la Comunidad de Madrid, pp. 61-72.

Baquedano, E., Márquez, B., Pérez-Gonzalez, A., Mosquera, M., Huguet, R., Espinosa, J.A., Sanchez-Romero, L., Panera, J., Arsuaga, J.L., 2011/2012. Neanderthales en el Valle del Lozoya: los yacimientos paleolíticos del Calvero de la Higuera (Pinilla del Valle, Madrid). Maniake XXXIII, 83-100.

Baquedano, E., Márquez, B., Laplana, C., Arsuaga, J.L., Pérez-González, A., 2014. los yacimientos arqueológicos de Pinilla del Valle (Madrid, España). In: Sala, R. (Ed.), Los cazadores recolectores del Pleistoceno y del Holoceno en Iberia y el estrecho de Gibraltar. Universidad de Burgos y Fundación Atapuerca, Burgos, pp. 577-584.

Barroso, C., Bailón, S., Guennouni, K., Desclaux, E., 2006. Les lagomorphes (Mammalia, Lagomorpha) du Pléistocène supérieur de la Grotte du Boquete de Zafarraya. In: Barroso, C., de Lumley, H. (Eds.), La grotte du Boquete de Zafarraya, Malaga, Andalousie. Monographies de L'Institut de Paléontologie Humaine, Tome II, Paris, pp. 893-926.

Blasco Sancho, M.F., 1995. Hombres, fieras y presas. Estudio arqueológico y tafonómico del yacimiento del Paleolítico medio de la cueva de los Moros de Gabasa 1. Huesca. Universidad de Zaragoza, Monografía 38.

Brugal, J.P.H., Raposo, L., 1999. Foz do Enxarrique (Rodão, Portugal): preliminary results of the analysis of a bone assemblage from a Middle Palaeolithic open site. In: The Role of Early Humans in the Accumulation of European Lower and Middle Palaeolithic Bone Assemblages. Monographien, 42. Römisch-Germanisches Zentralmuseum, pp. 367-379.

Bunn, H.T., Kroll, E.M., 1986. Systematic butchery by Plio/Pleistocene hominids at Olduvai Gorge, Tanzania. Current Anthropology 27, 431-452.

Bunn, H.T., Bartram, L.E., Kroll, E.M., 1988. Variability in bone assemblage formation from Hadza hunting, scavenging, and carcass processing. Journal of Anthropology 7, 412-457.

Cáceres, I., 1998. Le niveau I de l'Abric Romaní (Barcelone, Espagne): séquence d'intervention des différents agents et processus taphonomiques. In: XVIIIe Rencontres Internationales d'Archéologie et d'Histoire d'Antibes. Économie préhistorique: les comportements de subsistance au Paléolithique, pp. 173-180.

Cáceres, I., 2002. Tafonomía de yacimientos antrópicos en Karst. In: Complejo Galería (Sierra De Atapuerca, Burgos), Vanguard Cave (Gibraltar) y Abric Romaní (Capellades, Barcelona). Universitat Rovira y Virgili, Tarragona.

Callou, C., 1997. Diagnose différentielle des principaux éléments squelettiques du lapin (genre Oryctolagus) et du lièvre (genre Lepus) en Europe occidentale. In:
Desse, Dsse-Berset (Eds.), Fiches d'osteologie animale pour lárchéologie. Série B: MammifèresAPDCA, Valbonne-Sophia Antipolis.

Calzada, J., Palomares, F., 1996. Frecuencia de aparición de diferentes restos de conejo en excrementos de lince y zorro. Acta Vertebrata 23, 243-252. Doñana.

Chase, P.G., 1986. The Hunters of Combe Grenal: Approaches to Middle Pleistocene Subsistence in Europe. In: British Archaeological Reports, International Series 286. Oxford.

Cochard, D., 2004. Les léporidés dans la subsistance Paleolithique du sud de la France (Tesis Doctoral). Université Bordeaux

Cochard, D., 2007. Caractérisation des apports de léporidés dans les sites paléolithiques et application méthodologique à la couche VIII de la Grotte Vaufrey. In: XXVI Congrès Préhistorique de France. Centenaire de la Société Préhistorique Française (Septembre de 2005), vol. III, pp. 467-480.

Cochard, D., Brugal, J., 2004. Importance des fonctions de sites dans les accumulations paléolethiques de léporidés. Petits animaux et sociétés humaines. Du complément alimentaire aux ressources utilitaires. In: Brugal, J., Desse, J. (Eds.) XXIV recontres internatonales d'arqueologie et d'historie d'Antibes, pp. 283-296. Antibes.

Cochard, D., Brugal, J.-P., Morin, E., Meignen, L., 2012. Evidence of small fast game exploitation in the Middle Paleolithic of Les Canalettes Aveyron, France. Quaternary International 264, 32-51.

Costamagno, S., Laroulandie, V., 2004. L'exploitation des petits vértebrés dans les Pyrénées françaises du Paléolithique au Mésolithique: un inventaire taphonomique et archéozoologique. Petits animaux et sociétés humaines. Du complément alimentaire aux ressources utilitaires. In: Brugal, J.P., Desse, J. (Eds.), XXIVe Rencontres Internationales d'Archéologie et d'Histoire d'Antibes, Antibes, pp. 403-416.

Courty, M.A., Goldberg, P., Macphail, R., 1989. Soils and Micromorphology in Archaeology. Cambridge University Press, Cambridge, 364 pp.

Cowan, D.P., Bell, O.J., 1986. Leporid social behavior and social organization. Mammal Review 16 (3/4), 169-179.

Cruz-Uribe, K., 1988. Measuring species diversity and richness in archeological faunas. Journal of Archaeological Science 15, 179-196.

Cruz-Uribe, K., Klein, R.G., 1998. Hyrax and hare bones from modern South African eagle roosts and the detection of eagle involvement in fossil bone assemblages. Journal of Archaeological Science 25, 135-147.

Delibes, M., 1980. El lince ibérico. Ecología y comportamiento alimenticios en el Coto de Doñana, Huelva. Acta Vertebrata 7,1-128. Doñana.

Delibes, M., Hiraldo, F., 1981. The rabbit as a prey in the Iberian Mediterranean ecosystem. In: Myers, K., MacInnes, C.D. (Eds.), Proceedings of the I World Lagomorph Conference. University of Guelph, Ontario, Canada, pp. 614-622.

Delibes-Mateos, M., Gálvez-Bravo, L., 2009. El papel del conejo como especie clave multifuncional en el ecosistema mediterráneo de la Península Ibérica. Ecosis temas 18, 14-25.

Desclaux, E., 1992. Les petits vertebrés de la Caune de l'Arago à Tautavel (PyrénéesOrientals). Biostratigraphie, Paléoécologie et Taphonomie. Bulletin du Musée d'Anthropologie Préhistorique de Monaco 35, 35-64.

Dodson, P., Wexlar, D., 1979. Taphonomic investigation of owls pellets. Paleobiology 5, 275-284.

Fa, J.E., Stewart, J.R., Lloveras, L., Mario Vargas, J., 2013. Rabbits and hominin survival in Iberia. Journal of Archaeological Science 64, 233-241.

Fernández-Jalvo, Y., 1992. Tafonomía de microvertebrados del complejo kárstico de Atapuerca (Burgos). Tesis Doctoral. Universidad Complutense de Madrid.

Fernández-Jalvo, Y., Andrews, P., 1992. Small mammal taphonomy of Gran Dolina, Atapuerca (Burgos), Spain. Journal of Archaeological Science 19, 407-428.

Fernández-Jalvo, Y., Andrews, P., 2000. The taphonomy of Pleistocene Caves, with particular reference to Gibraltar. In: Stringer, C.B., Barton, R.N.E., Finlayson, C. (Eds.), Neanderthals on the Edge. Oxbow Books, Oxford, pp. 171-182.

Fernández-Jalvo, Y., Andrews, P., 2003. Experimental effects of water abrasion on bone fragments. Journal of Taphonomy 1 (3), 147-163.

Gardeisen, A., 2012. Un charnier dans le puits PT103. In: Fiches, J.L. (Ed.), Quatre puits de l'agglomération routière d'Ambrussum (Villetelle, Hérault), Revue Archéologique de Narbonnaise, 42, pp. 263-266.

Gardeisen, A., Valenzuela, S., 2004. À propos de la présence de lapins en contexte gallo-romain à Lattara (Lattes, Hérault, France). In: Brugal, J.P. Desse, J. (Eds.) Petits animaux et sociétés humaines. Du complément alimentaire aux ressources utilitaires. XXIVe Rencontres Internationales d'Archéologie et d'Histoire d'Antibes, Antibes, pp. 235-254.

Guennouni, K.E., 2001. Les lapins du Pleistocene moyen et superieur de quelques sites préhistoriques de l'Europe Mediterranéenne: Terra-Amata, Orgnac 3 Baume Bonne, Grotte du Lazaret, Grotte du Boquete de Zafarraya, Arma delle Manie. Etude Paleóntologique, Taphonomique et Archéozoologique. Thèse. Museum National d'Histoire Naturelle de Paris.

Hockett, B.S., 1996. Corroded, thinned and polished bones created by Golden Eagles (Aquila chrysaetos): taphonomic implications for archaeological interpretations. Journal of Archaeological Science 23, 7-591.

Hockett, B.S., Bicho, N.F., 2000. The rabbits of Picareiro Cave: small mammal hunting during the late Upper Palaeolithic in the Portuguese Estremadura. Journal of Archaeological Science 27, 715-723.

Hockett, B.S., Haws, J.A., 2002. Taphonomic and methodological perspectives of leporid hunting during the Upper Paleolithic of the Western Mediterranean Basin. Journal of Archaeological Method and Theory 9, 269-301.

Huguet, R., Arsuaga, J.L., Pérez-González, A., Arriaza, M.C., Sala-Burgos, M.T.N. Laplana, C., Sevilla, P., García-García, N., Álvarez-Lao, D., Blain, H.A. Baquedano, E., 2010. Homínidos y hienas en el Calvero de la Higuera (Pinilla del 
Valle, Madrid) durante el Pleistoceno Superior. Resultados preliminares. In: Baquedano, E., Rosell, J. (Eds.), Zona Arqueológica 13. Actas de la $1^{\text {a }}$ Reunión de científicos sobre cubiles de hiena (y otros grandes carnívoros) en los yacimientos arqueológicos de la Península Ibérica. Museo Arqueológico Regional, Alcalá de Henares, pp. 444-458.

Huguet, R., Saladié, P., Cáceres, I., Díez, C., Rosell, J., Bennàsar, M., Blasco, R., EstebanNadal, M., Gabucio, M.J., Rodríguez-Hidalgo, A., Carbonell, E., 2013. Successful subsistence strategies of the first humans in south-western Europe. Quaternary International 295, 168-182.

Jones, E.L., 2006. Prey choice, mass collecting and the wild European rabbit (Oryctolagus cuniculus). Journal of Anthropological Archaeology 25, 275-289.

Langenbach, G.E.J., Brugman, P., Weijs, W.A., 1992. Preweaning feeding mechanisms. Journal of Developmental Physiology 18, 253-261.

Langenbach, G.E.J., Weijs, W.A., Brugman, P., van Eijden, T.M.G.J., 2001 A longitudinal electromyographic study of the postnatal maturation of mastication in the rabbit. Archives of Oral Biology 46, 811-820.

Lloveras, L., Moreno-García, M., Nadal, J., 2008a. Taphonomic study of leporid remains accumulated by the Spanish Imperial Eagle (Aquila adalberti). Geobios 41 91-100.

Lloveras, L., Moreno-García, M., Nadal, J., 2008b. Taphonomic analysis of leporid remains obtained from modern Iberian lynx (Lynx pardinus) scats. Journal of Archaeological Science 35, 1-13.

Lloveras, L., Moreno-Garcia, M., Nadal, J., 2009a. The Eagle owl (Bubo bubo) as leporid remain accumulator: taphonomic analysis of modern rabbit remains recovered from nest of this predator. International Journal of Osteoarchaeology 19, 573-592.

Lloveras, L., Moreno-García, M., Nadal, J., 2009b. Butchery, cooking and human consumption marks on rabbit (Oryctolagus cuniculus) bones: an experimental study. Journal of Taphonomy 7, 179-201.

Lloveras, L., Moreno-García, M., Nadal, J., Maroto, J., Soler, J., Soler, N., 2010. The application of actualistic studies to assess the taphonomic origin of Musterian rabbit accumulations from Arbreda Cave (North-East Iberia). Archeofauna 19 99-119.

Lloveras, L., Moreno-García, M. Nadal, J.,Zilhão, J., 2011. Who brought in the rabbits? Taphonomical analysis of Mousterian and Solutrean leporid accumulations from Gruta do Caldeirão (Tomar, Portugal). Journal of Archaeological Science 38, 2434-2449.

Lloveras, L., Moreno-García, M., Nadal, J., 2012a. Feeding the foxes: an experimental study to assess their taphonomic signature on leporid remains. International Journal of Osteoarchaeology 22 (5), 577-590.

Lloveras, L., Moreno-García, M., Nadal, J., 2012b. Assessing the variability in taphonomic studies of modern leporid remains from Eagle Owl (Bubo bubo) nest assemblages: the importance of age of prey. Journal of Archaeological Science 39, 3754-3764.

Lyman, R.L., 1994. Vertebrate Taphonomy. Cambridge University Press, Cambridge, 524 pp.

Márquez-Mora, B., Mosquera, M., Baquedano, E., Panera, J., Pérez-González, A Espinosa, J.A., Arsuaga, J.L., Gómez, J., 2013. Evidence of a Neanderthal-madequartz-based technology at Navalmaíllo Rockshelter (Pinilla del Valle, Madrid Region, Spain). Journal of Anthropological Research 69, 373-395.

Martínez del Valle, R., 2001. Cazadores de Pequeñas presas. In: Villaverde, V. (Ed.), De Neandertales a Cromañones. El inicio del poblamiento humano en las tierras valencianas. Universitat de Valencia, pp. 129-130.

Martínez-Valle, R., 1996. La fauna del Pleistoceno Superior del País Valenciano. Aspectos económicos, huellas de manipulación y valoración paleoambiental. Departamento de Prehistoria. Universidad de Valencia, Valencia. Tesis Doctoral.

Michaeli, Y., Hirschfeld, Z., Weinreb, M.M., 1980. The cheek teeth of the rabbit: morphology, histology and development. Acta Anatomica 106 (2), 223-239.

Pérez-González, A., Karampaglidis, T., Arsuaga, J.L., Baquedano, E., Bárez, S., Gómez, J.J. Panera, J., Márquez, B., Laplana, C., Mosquera, M., Huguet, R., Sala, P., Arriaza, M.C., Benito, A., Aracil, E., Maldonado, E., 2010. Aproximación geomorfológica a los yacimientos del Pleistoceno Superior del Calvero de la Higuera en el Valle Alto de Lozoya (Sistema Central Español, Madrid). In: Baquedano, E., Rosell, J. (Eds.), Zona Arqueológica 13. Actas de la $1^{\text {a }}$ Reunión de científicos sobre cubiles de hiena (y otros grandes carnívoros) en los yacimientos arqueológicos de la Península Ibérica. Museo Arqueológico Regional, Alcalá de Henares, pp. 404-419.

Pérez-Ripoll, M., 1992. Las marcas de carnicería y la fracturación intencionada de los huesos de conejo. Marcas de carnicería, fracturas intencionadas y mordeduras de carnívoros en huesos prehistóricos del Mediterráneo español, Alicante, pp. 253-262.

Pérez-Ripoll, M., 2001. Marcas antrópicas en los huesos de conejo. In: Villaverde, V. Ed.), De Neandertales a Cromañones. El inicio del poblamiento humano en las tierras valencianas. Universitat de Valencia, pp. 119-124.
Pérez-Ripoll, M., 2005/2006. Caracterización de las fracturas antrópicas y sus tipologías en huesos de conejo procedentes de los niveles gravetienses de la Cova de les Cendres (Alicante). Munibe 57 (1), 239-254 (Homenaje a Jesús Altuna).

Pillard, B., 1969. Les données paléthnographiques apportées par la faune découverte sur le sol de la cabane du Lazaret. Une cabane acheuléenne dans la grotte du Lazaret (Nice). Henry de Lumley. Mémoires de la Société Préhistorique Française $7,177-181$.

Pillard, B., 1972. Les Lagomorphes du Würmien II de la Grotte de l'Hortus (Valflaunès, Hérault). Études Quaternaires, Mémoire 1, 229-232.

Rodríguez-Hidalgo, A., Saladié, P., Canals, A., 2013a. Following the white rabbit: a Case of a small game procurement site in the upper palaeolithic (Sala de las Chimeneas, Maltravieso Cave, Spain). International Journal of Osteoarchaeology 23 (1), 34-54.

Rodríguez-Hidalgo, A., Lloveras, L., Moreno-García, M., Saladié, P., Canals, A., Nadal, J., 2013b. Feeding behaviour and the taphonomic characterization of non-ingested rabbit remains produced by the Iberian lynx (Lynx pardinus). Journal of Archaeological Science 40, 3031-3045.

San Miguel, 2006. $1^{\text {a }}$ reimp. Manual para la gestión del hábitat el lince ibérico (Lynx pardinus Temminck) y de su presa principal, el conejo de monte (Oryctolagus cuniculus L.). Fundación CBD-Habitat, Madrid.

Sanchís-Serra, A., 2000. Los restos de Oryctolagus cuniculus en las tafocenosis de Bubo bubo y Vulpes vulpes y su aplicación a la caracterización del registro faunístico arqueológico. Saguntum 32, 31-50.

Sanchís-Serra, A., Fernández-Peris, J., 2008. Procesado y consumo antrópico de conejo en la Cova del Bolomor (Tavernes de la Valldigna, Valencia). El nivel XVIIc (ca $350 \mathrm{ka}$ ). Complutum 19 (1), 25-46.

Sanchís-Serra, A., Pascual-Benito, J.L., 2011. Análisis de la acumulaciones óseas de una guarida de pequeños mamíferos carnívoros (Sitjar Baix, Onda, Castellón): implicaciones arqueológicas. Archaeofauna. International Journal of Archaeozoology 20, 47-71.

Schmitt, D.N., Juell, K.E., 1994. Toward the identification of coyote scatological faunal accumulations in archaeological contexts. Journal of Archaeological Science 21, 249-262.

Stiner, M.C., 1994. Honor among Thieves: a Zooarchaeological Study of Neandertal Ecology. Princeton University Press, Princeton.

Stiner, M.C., Munro, N.D., Surovell, T.A., Tchernov, E., Bar-Yosef, O., 1999. Paleolithic population growth pulses evidenced by small animal exploitation. Science 283, 190-194.

Stiner, M.C., Munro, N.D., Surovell, T.A., 2000. The tortoise and the hare: small game use, the broad-spectrum revolution and Paleolithic demography. Current Anthropology 41, 39-73.

Terradas, X., Rueda, J.M., 1998. Grotte 120: un exemple des activités de subsistance au Paléolithique moyen dans les Pyrénées orientales. In: XVIIIe Rencontres Internationales d'Archéologie et d'Histoire d'Antibes. Économie préhistorique: les comportements de subsistance au Paléolithique, pp. 349-361.

Villa, P., Castel, C., Beauval, C., Bourdillat, V., Golberg, P., 2004. Human and carnivore sites in European Middle and Upper Paleolithic : similarities and differences in bone modification and fragmentation. Revue de Paleobiologie 23 (2), 705-730.

Villafuerte, R., 2007. Oryctolagus cuniculus (Linnaeus, 1758), 586 pp. In: Palomo, L.J. Gisbert, J., Blanco, J.C. (Eds.), Atlas y Libro Rojo de los Mamíferos Terrestres de España. Ministerio de Medio Ambiente, Madrid.

Villafuerte, R., Castro, F., 2007. El conejo de monte y los depredadores. Claves para o éxito na mellora das poboacións de coello en Galicia, Martínez Casal (coord.), pp. 62-69.

Villaverde, V., Martínez Valle, R., Guillem, P., Fumanal, M.P., 1996. Mobility and the role of small game in the Middle Palaeolithic of the central region of the Spanish Mediterranean: a comparison of Cova Negra with other Paleolithic deposits. In: Carbonell, E. (Ed.), The Last Neandertals, the First Anatomically Modern Humans. Cambridge University Press, pp. 267-288.

Weijs, W.A., Brugman, P., Grimbergen, C.A., 1989. Jaw movements and muscle activity during mastication in growing rabbits. The Anatomical Record 224, $407-416$.

Yardin, M., 1968. Evolution des dents du jeune lapin. Mammalia 32, 677-689.

Yravedra, J., 2004. Implications taphonomiques des modifications osseuses faites par les vrais hiboux (Bubo bubo) sur les lagomorphes. Petits animaux et sociétés humaines. Du complément alimentaire aux ressources utilitaires. In: Brugal, J.P., Desse, J. (Eds.), XXIVe Rencontres Internationales d'Archéologie et d'Histoire d'Antibes, Antibes, pp. 321-324.

Yravedra, J., 2008. Los lagomorfos como recursos alimenticios en Cueva Ambrosío (Almería, España). Zephyrus LXII, 81-99. 